\title{
The Relationship between Tax Rate, Penalty Rate, Tax Fairness and Excise Duty Non- compliance.
}

\author{
Perabavathi Sinnasamy* and Zainol Bidin \\ Tunku Puteri Intan Safinaz School of Accoutancy, Universiti Utara Malaysia, Malaysia
}

\begin{abstract}
The rise of indirect tax non-compliance by taxpayers became the main concern of most of the tax authorities around the globe. In Malaysia, non complaince such as smuggling and illegal trade activities by importers involving cigarettes, liquor and imported vehicles bound under Excise Act 1976 have caused revenue losses in monetary and nonmonetary aspects. Therefore, the objective of this study is to examine the relationship of tax rate, penalty rate and tax fairness of excise duty noncompliance. This study uses the Deterrence Theory as a basis theory to investigate the phenomenon of excise duty non complaince. A total of 500 excise duty offenders throughout Malaysia responded to the survey. The model was empirically tested by using Partial Least Squares (PLS) with disproportionate stratified random sampling technique. The results indicated that the perception of tax rate and penalty rate are positively related while tax fairness is negatively related to excise duty noncompliance among importers.
\end{abstract}

\section{Introduction}

Royal Malaysian Customs Department (RMCD) as indirect tax authority administering exports and imports of commodities and collect indirect taxes. The taxes collected contribute as a source of revenue to the federal government. However, the tax noncompliance occurs through unscrupulous importers by falsifying customs documents, under-declaration and hiding goods. Malaysia like any other countries faces a serious problem of Customs frauds yearly. This Customs frauds involved smuggling and illegal trade activities carried out by importers to avoid paying excise duty to RMCD.The taxpayers' non-compliance is the main issue encountered by RMCD. This agency looses revenue caused by the taxpayers' failure to pay excise duty. RMCD's statistics indicate that the additional excise duty detected from illegal trade activities and smuggling offences totalled almost more than RM1,800 million from the year 2010 to 2014 from the breakdown of 14,661 cases for cigarettes, 2,592 for imported vehicles and 4,662 for liquor [1]. These statistics shows that the problem of non-compliance need to be highlighted.

The tax non-compliance issue need to be investigated, in Malaysian context as developing country. Therefore, this study contributes several merits. First, it uses actual smuggling and illegal trade offenders (importers) to measure the non-compliance behaviour in Malaysia. Whereas, most of the researches are done studies on tax non-compliance using

* Corresponding author: mbasrpraba@yahoo.com 
annual reports which do not reflect the real situation. Secondly, this study contributes to the body of knowledge in indirect tax non-compliance in Malaysia. Finally this study tested the use of deterrence theory in Malaysian indirect tax environment. Furthermore, the understanding on excise duty non-compliance is still incomplete. This study will provide a fundamental awareness to RMCD as well as other researchers around the globe based on smuggling and illegal trade activities prevailing as a universal phenomenon.

\section{Literature review and hypotheses development}

\subsection{Deterrence Theory}

The Deterrence Theory by Becker [2] emphasized about economics of crime. Taxpayers are assumed to act under uncertainty position either to maximize their tax savings or face the punishment by comparing the cost incurred. This will be determined the compliance behaviour by weighing the chance of being detected and penalty acquisition. Based on explanation, this theory highlighted that by increasing tax rate and penalty rate will deter the non-compliance behaviour.

\subsection{Tax Non-compliance}

Tax non-compliance is defined as an illegal conduct of importers as taxpayers either done intentionally or unintentionally to evade taxes from tax authority. In Customs context tax non-compliance or tax frauds are mis-classification of tariff code, producing double invoices, falsifying country of origin [3].

\subsection{Tax rate}

Tax rate in Customs context is defined as an effect of the dollar paid for the import / export based on the Customs Harmonized System-nomenclature classification. In Customs perspective Fisman and Wei [4] found the higher the tax rates of the products the greater the revenue loss. Whereas In India, the effectiveness of tariff policies of customs duties evasion in 1990's tax reform examined by Mishra, Subramaniam and Topalova [5]. They found a positive effect between import tax evasion and Customs tariffs. Kubo and Lwin [6] investigated on smuggling offences related to import duties in Myanmar and identified increasing import duties caused smuggling. Therefore, the hypothesis developed for this study is:

$\mathrm{H}_{1}$ : Tax rate is positively related to excise duty non-compliance.

\subsection{Penalty Rate}

Penalty is defined as a deterrent measurement used by the tax authority on the taxpayers' [7]. The first systematic non-compliance behavior model originated by Becker [2]. Becker [2] assumed evaders will weigh the rewards and cost if they perform criminal behaviour by considering the severity of penalties and the risk of detection. Virmani [8] indicated that tax evasion and penalty rate have positive relationship, the higher the penalty rate, will induced people to behave dishonestly. Hence, the hypothesis developed is : 
$\mathrm{H}_{2}$ : Penalty rate is positively related to excise duty non-compliance.

\subsection{Tax Fairness}

Tax fairness in tax compliance can be defined in two different dimensions. The first dimension is on the benefit received with the dollars paid as tax. While the other one is on equity and the taxpayers' burden when referring to other individual in tax matters [9]. Azmi and Perumal [10] undertaken a study to recognized fairness perception within Malaysians taxpayers. The result showed perceived tax fairness positively influence tax compliance behaviour. The related hypothesis developed is as stated below:

$\mathrm{H}_{3}$ : Tax fairness is negatively related to excise duty non-compliance.

\section{Research theoretical framework}

This conceptual framework expanded from deterrence theory by considering noncompliance determinants such as tax rate, penalty rate and tax fairness.

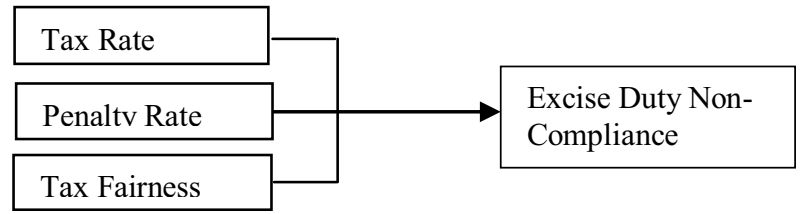

\section{Research methodology}

This study attempted to test the hypotheses developed in excise duty non-compliance. The population comprises of Managers who were committed in the cigarettes, liquor and imported vehicles offences throughout Malaysia. The survey was administered to the Manager as they are directly involved in importation declaration decision making. The sample obtained from RMCD's database for the year 2014. The questionnaires were distributed personally to 600 companies. After 4 months, 500 useable questionnaires returned. Therefore representing the response rate of $83 \%$. The participating companies' covers cigarette (223), followed by liquor (166) and imported vehicles (111). The items for all the constructs adapted from previous literatures to fit the study's objectives. All the main items were measured based on 7-point Likert Scale ranging from strongly disagree (1) and strongly agree (7). This study's survey items for tax rate, penalty rate and tax fairness adapted from previous literatures. The tax rate items was self employed. While penalty rate and tax fairness adapted from Devos [11] and Gilligan and Richardson [12] respectively.

\section{Findings}

SmartPLS version 3.2.4 which is variance based structural equation modelling (SEM) was employed to analyze research model based on the two-stage analytical procedures consists of measurement and structural model. Measurement model (outer model) tested for the validity and reliability of the measures. Followed by the structural model (inner model) evaluated by testing the hypothesized relationship. A bootstrapping method was used to test the path coefficient significant and the loadings [13]. 


\section{Assessment of measurement model}

The measurement model evaluates the relationships among the indicators and the constructs. Two types of validity were examined to assess the measurement model, the first is convergent validity followed by discriminant validity. Convergent validity is established by examining the indicators loadings, average variance extracted (AVE) and composite reliability. As shown in Table 1, indicator loadings for all items surpassed the threshold value of 0.50 as recommended by Hair, Hult, Ringle and Sarstedt [13]. However, the loadings for item tax rate item 1, penalty rate item 4, tax fairness item 3, 6 and 7 and excise duty non-compliance item 2,3, 4 and 6 were deleted due to low loading. The AVE values are higher than cut-off point of 0.50 . While, composite reliability greater than value 0.70 as suggested by Hair et.al. [13].

Table 1 Convergent validity

\begin{tabular}{llclc}
\hline \multicolumn{1}{c}{ Construct } & Items & Loadings & AVE & CR \\
\hline Excise duty non-compliance & EDN1 & 0.848 & 0.631 & 0.894 \\
(EDN) & EDN5 & 0.723 & & \\
& EDN7 & 0.877 & & \\
& EDN8 & 0.816 & & \\
& EDN9 & 0.691 & & 0.844 \\
Penalty rate & PR1 & 0.680 & 0.577 & \\
(PR) & PR2 & 0.735 & & \\
& PR3 & 0.738 & & \\
& PR5 & 0.871 & & \\
Tax fairness & TF1 & 0.853 & 0.752 & \\
(TF) & TF2 & 0.893 & & \\
& TF4 & 0.869 & & \\
& TF5 & 0.852 & & \\
Tax rate & TR2 & 0.800 & 0.675 & \\
(TR) & TR3 & 0.878 & & \\
& TR4 & 0.807 & & \\
& TR5 & 0.799 & & \\
\hline
\end{tabular}

Note: $\mathrm{CR}=$ Composite reliability; AVE average variance extracted

\subsection{Discriminant validity}

After confirming the convergent validity, the discriminant validity was assessed by using Fornell and Larcker [14] criterion. Discriminant validity is the degree which each construct differentiate from other construct in the research model. The square root of each construct's AVE should exceeds than all of the correlations between the construct and other constructs as shown Table 2 [15]. 
Table 2 Discriminant Validity

\begin{tabular}{lcccc}
\hline Construct & EDN & PR & TF & TR \\
\hline Excise Duty Non-compliance & $\mathbf{0 . 7 9 4}$ & & & \\
Penalty Rate & 0.347 & $\mathbf{0 . 7 5 9}$ & & \\
Tax Fairness & 0.606 & 0.286 & $\mathbf{0 . 8 6 7}$ & \\
Tax Rate & 0.256 & 0.144 & 0.324 & $\mathbf{0 . 8 2 2}$ \\
\hline
\end{tabular}

Diagonal values (bolded) are the square root of the average variance extracted while the other entries shows correlations.

\section{Assessment of structural model}

The structural model assessment involves evaluating $\mathrm{R}^{2}$, path coefficient ( $\beta$ values) and $t-$ values [13]. In this study, SmartPLS algorithm function is used to obtain the coefficient of determination $\left(\mathrm{R}^{2}\right)$ value. The result indicates that $\mathrm{R}^{2}$ value for excise duty non-compliance is .403 suggesting that $40.3 \%$ of the variance in excise duty non-compliance explained by tax rate, penalty rate and tax fairness. A bootstrapping technique with resampling of 1000 for 500 cases was applied to calculate the path coefficient and t- statistics values for hypothesized relationships. Table 3 shows the structural model's analysis results. The results revealed that tax rate $(\beta=0.056, p<0.05)$, penalty rate $(\beta=0.186, p<0.01)$ was positively related while tax fairness $(\beta=0.535, \mathrm{p}<0.01)$ negatively related to excise duty noncompliance which supported $\mathrm{H}_{1}, \mathrm{H}_{2}$ and $\mathrm{H}_{3}$ hypotheseses.

Table 3 Path Coefficient

\begin{tabular}{|l|c|c|c|}
\hline \multicolumn{1}{|c|}{ Relationship } & $\begin{array}{c}\text { Path coefficient } \\
(\beta \text { value })\end{array}$ & t-value & Decision \\
\hline Tax rate -> Excise duty non-compliance & 0.056 & $1.664^{* *}$ & Supported \\
\hline Penalty rate -> Excise duty non-compliance & 0.186 & $4.322^{*}$ & Supported \\
\hline Tax fairness -> Excise duty non-compliance & 0.535 & $13.974^{*}$ & Supported \\
\hline
\end{tabular}
$\mathrm{p}<0.01^{*} ; \mathrm{p}<0.05^{* *}$

\section{Discussion}

The present study's objective is to examine the relationship between tax rate, penalty rate and tax fairness with excise duty non-compliance. The findings revealed that tax rate is found to have positive relationship with excise duty non-compliance. This result is in line with the findings of previous literatures [4,5]. However, most of the theories does not provide clear prediction that the higher tax rate induces tax non-compliance. Therefore, this study sheds the light on excise duty as indirect tax claiming that the higher tax motivates the greater incentives to engage in fraud. Further, the higher tax rate will make the importers (tax payers) weigh between the risk aversion and fines for the successful tax evasion. Therefore, RMCD have to emphasize on the consequences of their tax reform especially on cigarettes, liquor and imported vehicles as the demand increases yearly. The solution for overcoming tax non-compliance is not by increasing excise duty (tax rate) as confirmed in this study.

This result showed that penalty rate is positively related to excise duty noncompliance. The finding is in line with previous studies by Virmani [8] and Alm, Kirchler and Muehlbacher [16]. The penalty imposed by RMCD is quite severe. For instance under Section 74 of Excise Act 1976 the penalty on evasion of excise duty is not less than 10 
times the amount of the excise duty of RM50,000 for illegal importation. While, for illegal manufacture of dutiable goods is RM10, 000. However, the importers still commit offences under excise duty. Therefore, in order to deter non-compliance, taxpayers should be able to understand the tax rules and regulations provisions. The excise tariff complexity under selfassessment in excise duty declarations has caused less confidence among importers to deter non-compliance.

The statistical analysis of this study revealed that tax fairness was found to have negative relationship on excise duty non-compliance parallel to the findings of prior literatures [10]. Therefore, it is concluded the contributing factor for this phenomenon is based on importers perception of excise duty paid and the public goods received in return. Importers judged the procedural fairness on excise rules and regulations provisions applied to them and the Customs Officers treatments in the declaration processes. Fair treatment to the taxpayers should not be like 'cops and robbers' that always find faults on taxpayers but by showing trust in them and not only deterrent behavior can solve the tax non-compliance phenomenon.

This study attempted to explore the tax compliance determinants in indirect tax context. Furthermore, based on our understanding this is the first study in Malaysia that highlighted excise duty non-compliance focused on cigarettes, liquor and imported vehicles among importers as taxpayers. Prior studies on indirect tax compliance and non-compliance vastly concentrated on goods and services or value added tax, import tax and sales tax. The application of theory mainly focused on Theory of Planned Behaviour and Theory of Reasoned Action as theoretical framework to predict the taxpayers' behaviour on tax noncompliance. Whereas, this study used Deterrence Theory in determining the importers noncompliance behaviour.

Moreover, this study's findings provides implications to RMCD as tax authority and policy maker. This revealed importers are looking forward for more friendly treatment rather than penalising them. Therefore RMCD should focus more on educating them on excise duty rules and regulations by conducting training to the importers. Most of the training provided emphasized on the tax agents rather than importers.

\section{Conclusions, limitations and future research}

This study has its strength and limitations as in other studies. There is a shortage of excise duty non-compliance empirical studies by practitioner experiences and observations. Specifically, on using actual excise duty offenders in tax non-compliance study. Therefore, this study has its own merits utilized the actual offenders those breached the tax laws, to investigate tax non-compliance behaviour among importers in Malaysia. However, like any other tax non-compliance studies this study has limitations mainly on using survey questionnaires method. Some of the sensitive and embarrassing issues are unable to be highlighted in structured questionnaire. Therefore as a suggestion, future research should be conducted by applying mix method approach to attain in depth understanding on tax noncompliance phenomenon. Further, the non-compliance behaviour is required to be extended and confirmed by using different methodological approaches. In line with this, several variables could be introduced such as peer influence, tax knowledge and corruption by considering probability of detection as a moderator. 


\section{References}

1. Royal Malaysian Customs Department, Annual report 2012-2014. Kuala Lumpur Percetakan Nasional Malaysia Berhad.

2. Becker, G. (1968). Crime and punishment : An economic approach. The Journal of Political Economy, 76(2), 169-217.

3. Thanasegaran, H., \& Shanmugam, B. (2007). International trade-based money laundering: the Malaysian perspective. Journal of Money Laundering Control, 10(4), 429-437.

4. Fisman, R., \& Wei, S.-J. (2004). Tax rates and tax evasion: Evidence from" missing imports" in China. Journal of Political Economy, 112(2), 471.

5. Mishra, P., Subramanian, A., \& Topalova, P. (2008). Tariffs, enforcement, and customs evasion: Evidence from India. Journal of public Economics, 92(10), 1907-1925.

6. Kubo, K., Lwin. (2010) Smuggling and import duties in Myanmar.

7. Devos, K. (2013). Do penalties and enforcement measures make taxpayers more compliant? The view of Australian tax evaders. Far East Journal of Psychology and Business, 12(1), 1-9.

8. Virmani, A. (1989). Indirect tax evasion and production efficiency. Journal of public Economics, 39(2), 223-237.

9. Jackson, B. R., \& Milliron, V. C. (2002). Tax Compliance Research. Taxation: Critical Perspectives on the World Economy, 3, 56.

10. Azmi, A. A. C., \& Perumal, K. A. (2008). Tax fairness dimensions in an Asian context: The Malaysian perspective. International Review of Business Research Papers, 4(5), 11-19.

11. Devos, K. (2005). Attitudes of tertiary students on tax evasion and penalties for tax evasion-A pilot study and demographic analysis. Journal of tax research, 3(2), 222-273.

12. Gilligan, G., \& Richardson, G. (2005). Perceptions of tax fairness and tax compliance in Australia and Hong Kong-a preliminary study. Journal of financial crime, 12(4), 331-343.

13. Hair Jr, J. F., Hult, G. T. M., Ringle, C., \& Sarstedt, M. (2016). A primer on partial least squares structural equation modeling (PLS-SEM): Sage Publications.

14. Fornell, C., \& Larcker, D. F. (1981). Evaluating structural equation models with unobservable variables and measurement error. Journal of Marketing Research, 39-50.

15. Chin, W. W. (2010). How to write up and report PLS analyses Handbook of partial least squares (pp. 655-690): Springer.

16. Alm, J., Kirchler, E., \& Muehlbacher, S. (2012). Combining psychology and economicin the analysis of compliance: From enforcement to cooperation. Economic Analysis and Policy, 42(2), 133-151. 